\title{
KANSALAISTUTKIMUS: IHAN PIHALLA? -PROJEKTIN LOPPUVAIHE JA TULOKSET
}

Briitta Koskiaho: YTT, sosiaalipolitiikean professori emerita, Tampereen yliopisto

briitta.koskiaho@tuni.fi

Janus vol. 27 (4) 2019, 299-307

Se, joka neuvoo jääräpäistä, tarvitsee itse neuvonantajan itselleen. Saadi, Ruusutarha (1259)

Januksen alkuvuoden numerossa kirjoitin kansalaistutkimuksesta yleensä ja projektin Ihan pihalla? alkuvaiheesta vuonna 2018 (Koskiaho 2019). Nyt projekti on valmis ja SOSTE ry:n järjestämä tiedotustilaisuus pidettiin kesäkuun lopussa 2019. Mitä siis jäi käteen tästä suomalaisessa sosiaalitutkimuksessa vielä vähän käytetystä tutkimusmetodista, koko prosessista ja tuloksista?

\section{TUTKIMUKSESSA KYSYTTIIN}

Kansalaistutkimus lähti liikkeelle konkreettisesta kysymyksestä: Miten vanhenevat ihmiset tulevat arkielämässään toimeen nyky-yhteiskunnassa, miten he pystyvät huolehtimaan oikeuksistaan ja täyttämään velvoitteitaan? Yhteiskunnallisten muutosten vauhti näyttää vain kiihtyvän ja yhteiskunnan eri toimintojen kompleksisuus kasvaa. Mukana seuraavat tietotekniikkaan liittyvät muutokset. Koko digimaailman moninaisuus avautuu yhteiskunnan eri toimijoiden käyttöön. Kompleksisuus ja digimaailman laajeneminen liittyvät markkinaliberalistiseen talouspolitiikkaan, joka toi markkinat ja niihin liittyvän taloudellisen kilpailun myös julkisen sektorin sisälle.
Miten tästä kokonaismuutoksesta selviytyvät ne, jotka ovat olleet eläkkeellä jo vuosia, toiset vuosikymmeniä, ja siten poissa työelämän muodostamasta yhteiskunnan ydintoiminnasta? Jo ennen vuosituhannen vaihdetta työelämästä poissiirtyneet eivät ehtineet kokea vielä työssä ollessaan nykyisen markkina-kilpailuyhteiskunnan vaikutuksia. He eivät vielä myöskään havainneet julkisen sektorin siirtymää entistä enemmän vain kansalaisten omaehtoisen toiminnan alustaksi, jolloin suorien tukitoimien osuus vähenee. "Kukin olkoon oman elämänsä seppä" -ajatteluun siirtyminen näkyy selvästi myös tehdyissä digitalisaation palveluuudistuksissa. Ne, jotka ovat siirtyneet vanhuseläkkeelle tällä vuosituhannella, ovat jo enemmän tai vähemmän kokeneet tämän muutoksen mutta siihen sopeutumisessa saattaa olla pulmia.

\section{YhTEISKUNNAN MUUTOSTEKIJÄT JA VANHAT IHMISET}

Nyky-yhteiskuntamme toiminnalliset peruspuitteet luotiin toisenlaista maailmaa eli toisen maailmansodan jälkeistä maailmaa varten vastapainoksi sille, että sota oli sotkenut eurooppalaiset yhteiskunnat, niiden toiminnot ja ihmisten elämän. Nyt, kohta kahdeksankymmentä vuotta tuosta sota-ajasta, yhteiskunnan kuuluukin jo toimia toisin 
kuin sodan jälkeisinä vuosina. Onko vanhojen ihmisten selviytyminen yhteiskunnassaan toisella tasolla kuin sodan aikana ja heti tämän jälkeen? Miten entistä pitkäikäisemmät kansalaiset sopeutuvat vanhetessaan yhteiskunnan kiihtyviin muutoksiin? Otetaanko eri muutosvaiheissa huomioon vähemmän muuntautumiskykyisten ja -tahtoisten selviytyminen? Sosiaalipolitiikan keskeisiä tehtäviä on ottaa huomioon kansalaisten oikeudet toimia kansalaisina. Erilaiset kansalaisvelvollisuudet lisääntyvät. Tarvitaan tukitoimia, avusteisen osallisuuden takaamista, jotta vanhat ihmiset selviytyvät tehtävistään kansalaisina.

Toisen maailmansodan jälkeisen sosiaalipolitiikan eetoksen mukaisesti on pyritty ulkoapäin takaamaan kaikille kansalaisille hyvinvoinnin perusteita, jotta kansalaiset sitten itse ponnistelisivat elättämään itsensä ja perheensä kunnon kansalaisen tavoin. Yhteiskunnan jatkuva kompleksoituminen ja digitalisoituminen tekevät näistä itseselviytymisen haasteista myös ongelmallisia.

Sodan jälkeisen maailman kehittämisen rationaalisuususkon mukaan toimenpiteillä otaksuttiin olevan odotetut seuraukset.Vähitellen havaittiin, että tilanteet ovatkin monimutkaisempia. Ratkaisuna on päällekkäisyyksien purkaminen ja rationaalisten toimintalinjojen näkeminen monimutkaistenkin verkostojen alta. Vähitellen alettiin tajuta, että monimutkaisuus voikin olla kompleksisuutta, jota ei voi purkaa osiin. Alettiin puhua holistisuudesta, kokonaisuuden huomioon ottamisesta ja erityisen vaikeista, äkäisistä (wicked) ongelmista, joihin vanhat menettelytavat eivät enää purreet (Bishop \& Dzidic 2014; Burns 2005; Glouberman \& Zimmerman 2002; Snyder 2015).

Itämaisessa filosofiassa painotetaan symbioosin korostamista. Kokonaisuuden eri osien tulee olla keskenään symbioottisessa ja harmonisessa suhteessa, jotta yhteisö tai yhteiskunta toimisi hyvin. Näin vältetään kompleksisuutta, joka ei ole palautettavissa osiinsa ja joka on jotain enemmän kuin osiensa summa (Koskiaho 2013).

Länsimaissa painotetaan kommunikaatiota, yhteyksien luomista erilaisten toimijoiden välille, jotta pystyttäisiin rakentamaan kokonaiskuvaa, holismia (Nijs 2015). Tähän liittyy myös osallisuuden ja sen edellytyksen, valtaistamisen, painottaminen. Yhteiskunnan jäsenten tulee voida vaikuttaa aidosti olosuhteisiinsa ja yhteiskuntaansa.

Vanhan ihmisen selviytyminen yhteiskunnassa kohtaa markkinatalouden intressit, joihin liittyy myös digimaailman kehitys. Ollaan kompleksisessa tilanteensa. Kompleksisuuden sieto on aloitettava siitä, että kaikki ymmärtävät kokonaisuuden eikä yhteiskunnan toimin alisteta jotain ryhmää, tässä vanhoja, niin että ryhmä syrjäytyy jo siitä syystä, ettei sen intressejä ja mahdollisuuksia oteta huomioon digivälineitä ja niiden käyttöä suunniteltaessa. Tällöin ei myöskään tunnisteta vanhojen ihmisten elämisen todellisuutta eikä osallisteta vanhoja uudistusten muovaamiseen tai käyttämiseen. Vanhojen ihmisten edellytyksiä selviytymiseen ei oteta huomioon.

Kompleksisuus on tunnustettava eikä sitä hävitetä soveltaen ylhäältä yksivii- 
vaisia rationaalisia keinoja (Chapman 2002). Monimutkaisuuteenkaan liittyvät keinot eivät auta. Tarvitaan holistisen kompleksisuuden ymmärtämistä. Symbioottisuudesta keinoksi tulee kokonaisuuden ymmärtäminen ja siitä yhteyksien ja osallisuuden tärkeyden merkitys.

Kansalaistutkimus voi olla sitä, että kansalaiset itse raportoivat ja analysoivat kompleksista tilannetta, osallistuvat tutkimusprosessiin ja miettivät toimenpide-ehdotuksia. He voivat myös itse toteuttaa uudistuksia yhdessä muiden toimijoiden kanssa (ks. Eitzel 2017).

\section{KOMPLEKSISUUS NÄKYY YKSILÖN ELÄMÄSSÄ}

Täyttä kansalaisuutta voivat tällä hetkellä heikentää yleisten yhteiskunnallisten syiden lisäksi myös vanhan ihmisen omaan elämäntilanteeseen liittyvät seikat, kuten:

liian pitkä poissaolo työelämästä etääntyminen organisaatioista, joihin pitäisi jatkuvasti olla yhteydessä,

tipahtaminen digitekniikan ja -käytön kehityksen nopeasti etenevistä vaiheista,

digikiinnostumattomuus, torjuva asenne tekniikkaa kohtaan,

turvautuminen muiden apuun, jolloin ei itse ole tarvinnut vaivautua asioiden hoitoon esimerkiksi digitekniikkaa käyttäen,

luottaminen siihen, että vanhat yhteydenpitotavat ja tutut toimipaikat asioinnissa säilyvät kautta aikojen vanhuuden myötä voimien heikkeneminen, sairaudet, näön ja kuulon vähittäinen heikkeneminen.

On vaara, että vanha ihminen vajoaa toiseuteen vaikka olisi koulutettukin henkilö. Tällöin kansalaisoikeudet eivät toteudu. Yhteiskunnan kannalta katsottuna on vaara, että tällaiset vanhat ihmiset lisäävät yhteiskunnan syrjäytyneiden kokonaismäärää. Syrjäytymisen sanotaan olevan luonteeltaan kulttuurista, sosiaalista, taloudellista tai etnistä. Näiden vanhojen ihmisten osalta se olisi kansalaisoikeuksista syrjäytymistä. Tällainen tilanne vaatii uusien toimintatapojen kehittämistä. Onko nyky-yhteiskunta rakentunut niin organisaatio-, talous- ja tekniikkakeskeiseksi, ettei se pysty huomioimaan uusia syrjäyttäviä mekanismeja? Maailmaa voidaan suunnitella kuitenkin vain osaksi, ja emergentit, odottamatta ilmaantuvat, tekijät muovaavat lopputulosta (Liebhart \& Garzia Lorenzo 2010).

\section{KANSALAISTUTKIMUKSEN KONKRETIAA}

Tutkimus lähti liikkeelle siitä, että epäiltiin vanhojen ihmisten irtautuvan yhteiskunnan muutosten melskeissä täydestä kansalaisuudesta, kansalaisoikeuksista ja näihin kuuluvasta vallasta, johon liittyy omien asioitten ajaminen. Vanhoihin ihmisiin kuuluivat kotonaan asuvat yli 75-vuotiaat, korkeakoulutetut henkilöt, joiden oletettiin yleensä olevan (vielä) kansalaistaitoisia.

Edellisessä Janus-puheenvuorossa (Koskiaho 2019) olen selostanut kansalaistutkimusta yleensä sekä sen soveltamista Ihan pihalla? -tutkimukseen.Varsinaisia 
kansalaistutkijoita projektissa oli 12 ja asiantuntijakansalaistutkijoita 14 , joista kaksi toimi kaksoisroolissa eli molemmissa tehtävissä. 75 vuotta täyttäneiden kansalaistutkijoiden lisäksi mukana oli myös ikääntyneiden omaishoitajia, ystäviä ja sukulaisia asioiden hoitajina, jotka kahta lukuun ottamatta olivat kaikki myös ikääntyneitä. Tutkimuksessa mukana olleiden julkisen ja kolmannen sektorin hankkeiden johtajat toimivat asiantuntijakansalaistutkijoina. Kaksi hankkeista liittyi sote-uudistukseen, Henkilökohtainen budjetti -hanke ja Asiakasohjaaja, Ikäneuvo, -hanke. Muiden hankkeiden alkuunpanija oli kolmannen sektorin toimija: Setlementti Tampere ry, Aunen ja Erkin Koti -säätiö Orivedeltä, Vanhusten asumisoikeusyhdistys JASO ry Jyväskylästä sekä pirkanmaalainen ATK Seniorit Mukanetti ry. Lisäksi asiantuntijakansalaistutkijoina toimivat Tampereen kaupungin vanhusasiamies ja virolainen tutkija virolaisen yhteiskehittämisen tutkimusaiheineen.

Kansalaistutkijat saivat itse raportoida ongelmiaan vapaasti sähköpostitse sen jälkeen, kun hyväksyivät osanottonsa tutkimukseen asioiden ajamisen tarpeesta arkielämän velvollisuuksista selviytymisessä. Tämä vaihe kesti noin puoli vuotta. Sen jälkeen hankkeiden johtajat kirjoittivat raporttinsa kukin omasta hankkeestaan. Lähtökohdaksi annettiin kansalaistutkijoiden raporttien perusteella tehty analyysi ongelmista. Alun perin oli ideana, että kaikki voisivat kokoontua kasvotusten muutaman kerran pohtimaan ongelmien ja hankkeiden toisiinsa soveltumista ja miettimään toimenpide-ehdotuksia. Kokoontuminen onnistui vain pirkanmaalaisten osalta, uusmaalaiset ja poh- jalaiset osanottajat jäivät ilman yhteisiä kokoontumisia.

Yhteydenpidon yleisvälineinä toimivat netti- ja puhelinyhteydet. Yhteydenpidon muihin kustannuksiin kohdistuneet kahdelle säätiölle osoitetut apurahahakemukset eivät tuottaneet tulosta. Säätiöille tämän kaltainen yhteiskuntatieteellinen tutkimustapa saattoi olla liian uutta ja kummallista. Projekti toimikin kokonaan vapaaehtoistoimintana.

Kokoontumisten perusteella voi kuitenkin uumoilla, että olisimme olleet vielä paljon innovatiivisempia, jos olisimme voineet puida yhdessä tutkimuksen eri vaiheita ja tuloksia. Yhteydenpito on kansalaistutkimuksen tutkimusprosessin ydinosa-aluetta. Kokonaisuudessaan Ihan pihalla? -projekti kesti puolitoista vuotta. Kuten aiemmassa puheenvuorossani mainitsin, keskuudestamme poistui tai siirtyi hoitokotiin osanottajia/heidän omaishoidettaviaan ensimmäisen puolen vuoden aikana - olihan kysymys vanhoista ihmisistä. Loppuvaiheessa kaikki hengissä olevat osallistuivat työskentelyyn. Yhteydenpidon intensiteetin taso kuitenkin vaihteli osallistujien kunnosta riippuen.

Suomalainenkin yhteiskunta monikulttuuristuu ja -kielistyy. Pientä uusmaalaista kaupunkia edustavat aistivammaiset ruotsinkieliset kansalaistutkijat saattoivatkin tuoda häivähdyksen niistä lisäongelmista, jotka myös suomalaisessa yhteiskunnassa ovat odotettavissa, kun maahanmuuttajien määrä kasvaa. Opittu suomenkieli häipyy taka-alalle ja alkaa olla asiointivaikeuksia myös viranomaisten kanssa. Esimerkiksi Britanniassa on ollut jo kauan käytössä vi- 
ranomaiskanssakäymisessä jopa monta kymmentä eri kieltä, mutta monikulttuurisuudella ja -kielisyydellä onkin britti-imperiumissa pitkä perinne.

\section{Minin JOUdUTtIIN}

\section{KANSALAISTUTKIMUKSEN POLULLA?}

Pelätyt ennakko-oletukset täyttyivät aivan liiankin hyvin. Tähänkö on tultu pitkäaikaisen hyvinvointivaltiollisen uurastamisen tuloksena? Ovatko tulevaisuuden vanhenevat ihmiset myös syrjäytymässä, kun yhteiskunta siirtyy aina uuteen vaiheeseen? Missä on sosiaalinen integraatio ja missä sosiaalinen inkluusio?

Koulutus ei sinänsä auta, kun yhteiskunnan toiminta tahattomasti tuottaa toiseutta jollekin kansalaisryhmälle, nyt 75 vuotta täyttäneille, joiden määrä kasvaa tulevina vuosikymmeninä eniten kaikista ikäryhmistä. Lisääntyykö siis toiseus edelleen kumulatiivisesti?

Kansalaistutkijat olivat kaikki enemmän tai vähemmän avuttomia yhteiskunnan muutosten edessä asioidensa hoitamisessa. Erityisesti pääkaupunkiseudulla taistelu kotipalvelun byrokratian kanssa kustannuksista ja niiden oikein laskemisesta oli piinallista luettavaa vanhojen sairaiden ja omaishoitajien kohdalla. Pankkiasiointi niiden osalta, jotka ovat jääneet digiasioinnissa muista jälkeen, on myös suuri ongelma erityisesti suurten pankkien osalta. Viranomaisasioinnin monet olettavat sujuvan samaan tapaan kuin joskus aiemmin henkilökohtaisen tapaamisen painottamisen aikoihin. Niinpä digiyhteydenpidon korostaminen tuottaa kaiken kaikkiaan ahdistusta monelle.
Parhaiten näyttivät kuitenkin selviävän ruotsinkieliset uusmaalaiset, jotka asuivat pienessä kaupungissa tuttujen ihmisten ja organisaatioiden keskellä. Erityisesti kolmannen sektorin aistivammaisia palvelevat järjestöt tekivät työnsä kiitettävästi. Sosiaalinen inkluusio toimi omassa eristetyssä kuplassa, mutta suureen maailmaan joutuminen taas oli heti kuin kylmä suihku niskaan: Pääkaupunkiseudun sairaaloissa kieliongelmat toivat turvattomuutta. Suomenkielisiä palveluja välteltiinkin kieliongelmien vuoksi. Voidaankin kysyä, miten selviydytään maahanmuuttajien kasvavien joukkojen kanssa tulevaisuudessa, kun jo perinteinen kotimainen kieli- ja kulttuuriero tuottaa vaikeuksia. Maahanmuuttajat ovat sopeutuneet suomalaiseen elämänmenoon yleensä mutkattomammin ruotsinkielisillä vähemmistökulttuuripaikkakunnilla kuin valtakulttuurin alueilla.

\section{MITÄ TÄSTÄ PITÄISI OPPIA?}

Ainakin se, että valmiudet kohdata uudenlainen digimaailma ovat hyvin erilaiset vanhojen ihmisten ryhmässä. Osa on pelottavan kaukana siitä, minkä oletetaan olevan normikansalaisen valmiustaso. Osa myös kieltää uusien haasteiden olemassaolon omalta kohdaltaan kokonaan.

Hankkeilla oli tarkoitus helpottaa vanhojen ihmisten elämää. Sotehankkeissa ennakoitiin ja pilotoitiin soteuudistuksen eri puolia. Pirkanmaalainen Ikäneuvo pyrki kehittämään palveluohjausta. Puhuttiin asiakasohjauksesta, koska asiakkaiden elämässä on muutakin kuin vain sosiaali- ja terveyspalvelut. Uusmaalainen henkilökohtaisen 
budjetin hanke pyrki kehittämään laajapohjaisesti henkilökohtaista budjettia valinnanvapautta kunnioittaen. Budjetti annettaisiin sosiaalipalveluasiakkaan käyttöön, jolloin ei suoraan määritellä palvelua ja sen käyttöä. Vuonna 2018 hallinnon kehitelmissä yksilöitiin jo konkreettisesti henkilökohtaisen budjetin soveltamisen sääntöjä. Ne perustuivat budjetin keskittämiseen peruspalveluihin ja siten valinnanvapauden rajoittamiseen. $\mathrm{Ne}$ olivat ristiriidassa aiemman hankkeen valinnanvapautta kunnioittavalle ajattelulle ja samalla henkilökohtaisen budjetin perusideoille. Vanhat ihmiset määritettiin ennalta määritettyjen peruspalvelujen käyttäjiksi!

Kolmannen sektorin hankkeissa eli yksityisen säätiön yhteiskehittämisessä Orivedellä, jyväskyläläisessä ikääntyneiden asumisoikeuden uudistamisessa, setlementtiliikkeen asumiseen ja neuvontaan liittyvissä hankkeissa sekä pirkanmaalaisen yhdistyksen toteuttamassa digiohjauksen vertaistukijärjestelmässä tuli selvästi ilmi se, kuinka tärkeätä on, että hankkeen takana on päteviä asiantuntijoita, verkostoja ja rahoitusta.

Kolmannen sektorin hankkeilla on Suomessa yleensä taipumus jäädä hajanaisiksi. Rahoitusta tulee jollekin suunnitelman osa-alueelle, jos tulee. Resurssien ulkoapäin tapahtuva rajaaminen ja suuntaaminen vaikuttaa hankkeiden painotuksiin ja toteutumiseen. Kolmannen sektorin organisaatiot tarvitsevat kovan luokan ammattilaisia ja näiden kontakteja tuekseen selviytyäkseen.

Suomalaisten esimerkkien lisäksi mukana oli virolainen yhteiskehittämi- nen paikallisine sovelluksineen. Virolaiset painottavat julkisen sektorin ja paikallisten yhteisöjen kumppanuuksien kehittämistä vanhojen ihmisten selviytymisessä ja asioiden hoitamisessa.

Hankkeista lähimmäksi kansalaistutkijoiden, ja siten oletettavasti yleisemminkin vanhojen kansalaisten, ongelmia näyttivät tulevan hankkeet, joissa oli kysymys asumiseen liitetystä neuvonnasta, joka johtaa aina asioiden syvempään ajamiseen. Vanhojen ihmisten asiat kannattaa hoitaa lähellä heidän elämänpiiriään. Se on silloin helpointa. Sotehankkeet koettiin enemmän byrokraattisiksi kuin asiakaslähtöisiksi, vaikka hankkeissa tuotiin esille sitä, että kysymys on asiakkaitten neuvonnasta ja eduista. Vanhoja ihmisiä ei ollut suunnittelemassa uudistuksia, jotka kohdistuvat heidän ryhmäänsä.

\section{MIKÄ TULOKSISSA YLLÄTTI VERRATTUNA ENNAKKO-OLETUKSIIN?}

Ilmiselvästi yllättävää oli, että myös koulutetut ihmiset joutuvat vanhetessaan niinkin syrjään kehityksestä ja välineistä auttaa itse itseään kuin nyt tapahtui. Toiset ponnistelevat kiivaasti tätä toiseusprosessia vastaan, toiset ovat jo sopeutuneet siihen. Kompleksisesta kokonaisuudesta, joka sisältää toiseutta, on vaikea ponnistella pois.

Yllättävää oli myös se, miten ulkolähtöistä julkisen sektorin innovaatiotoiminta on yhä edelleen. Kansalaisilla ei ole hankkeisiin tarttumakohtia. Kolmannen sektorin hankkeet voivat jäädä hajanaisiksi. Niitä rahoitetaan irrallaan toisistaan, kuten voi lukea myös entisen Raha-automaattiyhdistyksen, nykyisen 
STEAn, rahoituksen kohdeluetteloista. Miksi kolmannen sektorin hankkeita ei ryhmitetä temaattisesti ja pyritä ratkaisemaan jotain suurempaa ongelmaa systemaattisesti osien avulla? Hankkeet pitäisi kytkeä myös julkisen sektorin uudistuksiin kumppanuuksin avainkäsitteinä jatkuvuus ja integraatio.

Asioiden ajaminen näyttää vaikeutuvan mitä pidemmälle erityisesti julkisen sektorin digitalisaatio etenee niiden ryhmien kohdalla, jotka ovat digikehityksestä kaukana. Kolmannen sektorin toimijoiden digiopetus tapahtuu ilman keskinäistä koordinaatiota. Valtion tavoitteena on, että kaikki julkiset palvelut siirtyvät parin vuoden sisällä pääsääntöisesti digitalisaation piiriin ja mobiilipalveluiksi. EU:n direktiivimuutoksen vuoksi mobiilipalveluihin pitäisi siirtyä jo 2019 pankkipalveluiden maksuliikenteen osalta ilman, että muutoksiin olisi erityisesti varauduttu heikoimmin digikehityksen muutoksiin sopeutuvien osalta.

Suomalaista digivälinekehitystä näyttää myös hidastuttavan kieliongelma. Suomi on taloudellisesti liian suppea kielialue, jotta muualla kiihtyvästi kasvava puheohjaus ja puheentunnistus etenisi myös niiden palveluihin, joilla muuten on vaikeuksia sopeutua digimuutokseen. Puheen käyttö digiyhteyksissä esimerkiksi maksupalveluissa toisi suuren helpotuksen digimaailmaa pelkäävien kommunikointimahdollisuuksiin. Samalla huomiota kiinnitetään kuitenkin kustannuksiltaan kalliiden erityisvammaisille tarkoitettujen kommunikaatiovälineiden kehittämiseen ja toisaalta nuorten tietotekniikkainsinöörien omaan kokemusmaailmaan parhaiten soveltuvien uudistusten kehittämiseen.
Sovellukset, jotka eivät vaadi nuoren ihmisen näppäryyttä, mukautuvuutta tai taitoja, näyttävät tulevan aina perässä.

Nämä intressit eivät ole teknisen kehittämispolitiikan kärjessä. Valtion digipolitiikan asiakirjoissa korostetaan digipalveluiden soveltuvuutta kaikelle kansalle. Heikkojen ryhmien edustajia pitäisi saada teknisiksi myötäkehittäjiksi ja keksintöjen testaajiksi kehittämisvaiheeseen. Todellinen kansanvaltaistaminen näyttää olevan yhä edelleen toissijaisessa asemassa teknisissä innovaatioissa. Muutos hälventäisi kompleksisuuden ongelmia.

\section{KONKREETTISET SUOSITUKSET}

Tutkimusprosessin eri vaiheissa nousi esiin kolme kehittämisesitystä neuvonnan ja asioitten ajamisen organisoinnista, asiantuntijakoulutuksesta sekä koko ongelman siirtämisestä yleisen digipolitiikan keskiöön. Konkreettiset suositukset ovat:

Kumppanuuteen perustuvat kunnan keskustan neuvontakeskukset luotseineen

Korttelikeskukset, joihin keskitetään asukkaiden neuvonta ja luotsitoimintaa

Luotsikoulutus sekä sosiaali- ja terveyspalvelujen henkilökunnan lisäkoulutus neuvontaan, opastukseen ja asioiden ajamiseen

Digiministeri ainakin alkuun - digitalisaation ohjaus ja koordinaatio kaikilla aloilla yhteen 
Muutkin kuin vanhat ihmiset voivat tarvita arkielämän asioiden hoitamisessa apua. Julkinen hallinto on vastuussa kansalaisten pysymisessä täyden kansalaisuuden piirissä. Kuntiin tulisi saada yleinen neuvontakeskus, jossa olisi tilaa myös nyt hajallaan olevien eri järjestöjen neuvontatoimelle. Tämä kumppanuus pitäisi organisoida taitavasti. Digivälineet ja -palvelut ovat toiminnan ytimessä. Asuinkortteleihin tulisi saada urbaaneilla alueilla oma neuvonta- ja ohjausyksikkö, johon voisi yhdistää myös kotipalvelujen tukipisteen ja ehkä myös talojen isännöinti- ja huoltopalvelut. Maaseudulla kylät voisivat olla toimintatasoina.

Neuvonta ja ohjaus tarvitsevat myös uudenlaista koulutusta. Porin ammattikorkeakoulussa on jo ollut harkinnassa luotsikoulutuksen tarve. Kansalaistutkijat ehdottavat omiin kokemuksiinsa perustuen sitä, että erityisesti sairaanhoitoyksiköissä pitäisi henkilökunnalle suunnata neuvonta- ja asioidenajokoulutusta, jotta henkilökunta pystyisi antamaan tällaista ensiapua, ymmärtämään potilaiden tarpeet ja ohjaamaan nämä eteenpäin saamaan neuvontaa ja ohjausta. Sairaaloiden sosiaalityöntekijät on työllistetty nykyään muilla tehtävillä. Alun perin juuri tämä luotsitoiminta on ollut heidän osaamisaluettaan.

Yksityisen sektorin haasteisiin emme pystyneet antamaan erityisiä suosituksia. Arkielämän vaateiden hoitamisessa etualalle nousivat pankkipalvelut. Toiveena oli digipalvelujen saaminen mahdollisimman nopeasti sellaiseen muotoon, joka palvelee niitä, joilla ei ole samoja taitoja eikä kokemuksia digimaailmasta kuin nuorilla. Tämän hetkistä tilannetta pidettiin hälyttävä- nä. Varsinkin suuret pankkikonsernit näyttävät palvelevan näitä vanhoja asiakkaitaan huonosti. Kansalaistutkijat odottavatkin uusia rahaliikenteen toimijoita, jotka ymmärtävät tämän kaltaisen asiakaskunnan tarpeita ja osaavat kehittää toimiaan tälle asiakaskunnalle soveltuviksi.

Jotta digipolitiikan kokonaisuudessa pystyttäisiin huomioimaan vanhojen ihmisten tarpeet, tarvittaisiin maahan ainakin toistaiseksi digiministeri, joka pystyisi aloittamaan eri alojen digikehityksen koordinoinnin, neuvonnan ja ohjauksen. Erityisen ongelmalliseksi nähtiin se, että terveydenhuollon eri yksiköt eivät koordinoidu potilastietojen välittämisessä vieläkään toisiinsa, vaikka ongelma on ollut esillä jo pitkään. Tilanne on jopa irvokas juuri niiden kannalta, jotka eivät itse sairaina kykene huolehtimaan potilastietojensa siirtymisestä organisaatiosta toiseen ja siitä muistuttamisesta. Digiministerin tarve korostuu, jotta kokonaisuus saataisiin hallintaan.

Päädyimme lopputulokseen: Vanhat ihmiset on valtaistettava, jotta he voivat edes avusteisesti hoitaa omia asioitaan! Tähän tulokseen voi tulla myös niistä kansainvälisistä kokemuksista, joita tutkimusraportissa käsitellään. Tutkimusraportin (Koskiaho \& Saarinen toim. 2019) ja sen lyhennelmän on julkaissut 2019 SOSTE ry. Vuoden 2018 aikana julkaistiin projektista useita artikkeleita eri eläkeläisjärjestöjen lehdissä. Tarkoituksena oli järjestöjen ja niiden jäsenten aktivointi, yksi kansalaistutkimuksen tehtävä sekin. 


\section{KirJallisuUs}

Bishop, Brian J. \& Dzidic, Peta (2014) Dealing with Wicked Problems: Conducted a Causal Largered Analysis of Complex Social Psychological Issues. American Journal of Community Psychology, 53 (1-2), 13-14.

Burns, Bernard (2005) Complexity theories \& Organizational change. International Journal of Management Reviews, 7 (2), 73-90.

Chapman, Jake (2002) System failure. Why government must learn differently. DEMOS. London.

Eitzel, M.V. ym. (2017) Citizen Science Terminology Matters: Exploring Key Terms. Citizen Science: Theory and Practice, 2(1),1. DOI: http://doi. org/10.5334/cstp.96

Glouberman, Sholom \& Zimmerman, Brenda (2002) Complicated and complex problems. What would a new perspective on medicare look like? Commission on the Future of Health Care in Canada. Discussion Paper No 8. https:// www.alnap.org/system/files/content/ resource/files/main/complicatedandcomplexsystems-zimmermanreportmedicare-reform.pdf Luettu 2.7.2019.

Koskiaho, Briitta (2013) Aika, kompleksisuus ja sen hallinta ajassa. Acta Futura Fennica 5 B-osa. Tulevaisuuden tutkimuksen seura ry (alkuper. artikkeli vuodelta 1993). www.tutuseura.fi
Koskiaho, Briitta (2019) Kansalaistutkimus: toisenlaista tutkimusta. Janus 27 (1), 72-78.

Koskiaho, Briitta \& Saarinen, Erja (toim.) (2019) Ihan pihalla? Vanhat ihmiset digitaalisen maailman myllerryksessä: neuvonnan, ohjauksen ja asioiden ajamisen järjestäminen. Helsinki: Soste ry. https:// www.soste.fi/ihan-pihalla/ luettu 10.8.2019.

Liebhart, Margrit \& Garcia Lorenzo Lucia (2010) Between planned and emergent change: Decision maker's perspections of managing change in organizations. The International Journal of Knowledge, Culture and Change Management, vol. 10 (5), 214-225.

Nijs, Diane E.L.W. (2015) The Complexity - Inspired Design Approach of Imagineering. World Futures vol. 71 (1-2), 8-25.

Snyder, Sean (2013) The Simple, the Complicated, and the Complex: Educational Reform Through the Lens of Complexity Theory. OECD Education Working Papers No. 96. OECD Publishing. http:// dx.doi.org/10.1787/5k3txnpt1lnr-en Luettu 2.7.2019. 